\title{
The Effectiveness of Crocatum Piper and Annona Muricata L Leaves Toward Leukorrhea in Hormonal Contraception Acceptors in the Working Area of Regional Public Service Agencies of Public Health Center in Tembelang
}

\author{
Zeny Fatmawati ${ }^{1 *}$, Elly Rustanti ${ }^{2}$ \\ \{Zenyjoe123@gmail.com ${ }^{1}$ \}
}

Sekolah Tinggi Ilmu Kesehatan Husada Jombang ${ }^{1,2}$

\begin{abstract}
The purpose of this study is to determine the effectiveness difference of red betel plus soursop leaves decoction and soursop leaf decoction against leukorrhea in hormonal contraceptive acceptors in the working area of Regional Public Service Agencies of Public Health Center in Tembelang. It is a pre-experimental research design with two groups pretest and post test design. The population is all of the hormonal contraceptive acceptors who had leukorrhea in the Regional Public Service Agencies of Public Health Center in Tembelang. 30 subjects group of cases with vaginal wash treatment using red betel mixed with soursop leaves decoction and 30 subjects control group with vaginal wash treatment using soursop leaf decoction. The samples were taken by using purposive sampling technique which the independent variable was vaginal wash treatment using red betel and soursop leaves decoction, and the dependent variable is Leukorrhea. The research instrument used was the observation sheet and the data were analyzed by using the $\mathrm{T}$ test. The $T$ test of the two treatments was statistically significant with $P$ value is 0.001 . The decoction of red betel (Piper Croratum) leaf and soursop (Annona Muricata L) leaf is more effective in curing complaints of leukorrhea in women who experience female reproductive organs problems related to leukorrhea.
\end{abstract}

Keywords: Effectiveness difference, effectiveness of piper croratum and annona muricata L, leukorrhea

\section{Introduction}

Leukorrhea should not be underestimated because it can cause serious problems in the external female reproductive organs, such as genetalia, pain during sexual intercourse, infections that cause genetalia odema, burning sensation in the vagina, etc. Almost all women in the world experience vaginal discharge, at least once and twice or more in a lifetime. In Indonesia, the prevalence of women experiencing leukorrhea at least once in their life is $75 \%$ and women who experience Leukorrhea more than or equal to twice is $45 \%$. Hormonal contraceptives are contraceptives in which estrogen and progesterone provide feedback to the pituitary gland through the hypothalamus, causing obstruction to the follicles and the ovulation process [3]. 
Fluor albus, which is sometimes found in hormonal contraceptives with high doses of progesterone, is caused by the increase of infection with candida albicans. Leukorrhea is a sign of cervical cancer. Cervical cancer is the fourth most common cancer among women in worldwide. In 2012, the incidence of cervical cancer in the world was 528,000 new cases with a death rate of 266,000. Human Papilloma Virus (HPV) is a sexually transmitted infection that causes cervical cancer. The low and high risk of HPV against cervical cancer depends on the involvement of other factors, namely parity and contraceptives [4]. Red betel leaf contains alkaloids that green betel does not have as an antimicrobial and it also has an antiseptic power twice as high as green betel leaf. The red betel decoction has not only antimicrobial content and antiseptic power higher than green betel, but also carvacrol which is used as disinfectant and anti-fungal so that it can be used as an antiseptic medicine to maintain the health of the oral cavity, cure vaginal discharge and bad odor [2].

Soursop leaves (Annona muricata L.) contain alkaloid compounds, polyphenols, flavonoids, triterpenoids, some of which are considered to have inhibitory activity against fungi, especially Candida albicans which is the main cause of infection with candidiasis vaginalis [5]. The highest antifungal effectiveness of the active compound in soursop leaves was the NHexane fraction with an inhibitory diameter of $23.7 \mathrm{~mm}$ which was categorized as stronger than the positive control for ketoconazole with an inhibition zone of $22,5 \mathrm{~mm}$ and $15.9 \mathrm{~mm}$ of nystatin. Soursop leaves can be used to treat vaginal discharge in women because they contain antiseptic substances that can kill germs, namely phenol, where exist in the soursop leaves which has antiseptic properties 5 times more effective than the ordinary phenol, to treat vaginal discharge [7]. The purpose of this study was to analyze the effectiveness differences of red betel and soursop leaves against Leukorrhea in hormonal contraceptive acceptors in the Regional Public Service Agencies of Public Health Center in Tembelang, Jombang. It also can be used as an educational material and alternative complementary medicine against Leukorrhea in women.

\section{Method}

The research design used in this study was a pre-experimental two group with pretest and post test design (Table 1). It is an experimental design by observing the incidence of leucorrhea first, then giving the intervention, next is observing changes in the incidence of leucorrhea (8). 
Table 1. Research Model

\begin{tabular}{ccll}
\hline Subject & Pre test & \multicolumn{1}{c}{ Treatment } & \multicolumn{1}{c}{ Post test } \\
\hline $\mathrm{A}^{1}$ & Observation & Soursop and Red Betel Leaf Decoction & Observation \\
$\mathrm{A}^{2}$ & Observation & Soursop Leaf Decoction & Observation \\
\hline
\end{tabular}

The population in this study were hormonal contraceptive acceptors in the working area of Regional Public Service Agencies of Public Health Center in Tembelang, Jombang. The sample was taken by purposive sampling technique with a total of 60 research subjects, 30 research subjects were given vaginal wash treatment using soursop leaf decoction and 30 research subjects were given treatment wash the vagina using a decoction of a mixture of red betel leaf and soursop and has passed the research ethics test.

This research was conducted at a Midwife's Independent Practice of Niken Kinesti in Pulogedang Village, Tembelang and a Midwife's Independent Practice of Khusnul Chabibah in Mojokrapak Village, Tembelang, on August 15 - September 15 2020, The independent variables of this study was the treatment by using a decoction of soursop leaves and a mixture of red betel and soursop leaf, while the dependent variable was Leukorrhea, The ingredients of this research were the decoction of soursop leaves and a mixture of red betel and soursop leaf with a concentration of $2 \%$, which is 10 grams in $500 \mathrm{ml}$. The research instrument was an observation sheet which was carried out for 5 treatment days. Every day, the vaginal was washed twice with $200 \mathrm{ml}$ of decoction. The research instrument of this study was the observation sheet. The data analysis was done through univariate and bivariate distribution tables by using the T test.

\section{Results and Discussion}

\subsection{Results}

Table 2. The Frequency Distribution of General Characteristics of Subjects Effectiveness of Soursop and Red Betel Leaf Decoction on Leukorrhea at Hormonal Contraceptive Acceptors in the Working Area of Regional Public Service Agencies of Public Health Center in Tembelang, Jombang in the year of 2020

\begin{tabular}{llll}
\hline & Characteristics & N & \% \\
\hline Age & $<20$ years old & 2 & 3.30 \\
& $20-35$ years old & 33 & 55.0 \\
& $>35$ years old & 25 & 41.7 \\
\hline Weight & $40-55 \mathrm{~kg}$ & 17 & 28.3 \\
& $56-65 \mathrm{~kg}$ & 22 & 36.7 \\
& $>65 \mathrm{Kg}$ & 21 & 35.0 \\
\hline Contraception & 1 month injection & 19 & 31.7 \\
Method & 3 months injection & 19 & 31.7 \\
& Pill/ Tablet & 20 & 33.3 \\
& Implant & 6 & 3.3 \\
\hline The length of use & $<3$ years & 29 & 48.3 \\
& $\geq 3$ years & 31 & 51,7 \\
\hline Job & Housewife & 55 & 92.0 \\
& Not a housewife & 5 & 8.0 \\
\hline Educational status & Elemetary - Middle & 20 & 33.3 \\
& High School & 35 & 58.3 \\
& Undergraduate & 5 & 8.4 \\
\hline
\end{tabular}




\begin{tabular}{llll}
\hline Paritas & $1 \mathrm{x}$ & 23 & 58.3 \\
& $2 \mathrm{x}$ & 30 & 50.0 \\
& $\geq 3 \mathrm{x}$ & 7 & 11.7 \\
\hline
\end{tabular}

Table 2 shows that most of the subjects were $55 \%$ in the age of $20-35$ years old, $35 \%$ of body weight is more than $65 \mathrm{~kg}$, the most widely used hormonal contraceptive method was consuming pill/ tablet contraception as much as $33.3 \%$, the length of time using hormonal contraception was mostly more than 3 years was $51.7 \%, 58.3 \%$ of the education background was senior high schools and parity once in a lifetime is $58.3 \%$

Table 3. The Frequency Distribution of Research Variables Effectiveness of Soursop and Red Betel Leaf Decoction on Leukorrhea in Hormonal Contraceptive Acceptors in the Regional Public Service Agencies of Public Health Center in Tembelang, Jombang in the year of 2020

\begin{tabular}{lcccc}
\hline \multirow{2}{*}{$\begin{array}{c}\text { Treatment } \\
\text { Soursop and Red Betel leaf } \\
\text { decoction }\end{array}$} & \multicolumn{2}{c}{ Lecoverd } & \multicolumn{2}{c}{ Not fully recovered } \\
\cline { 2 - 5 } & \multicolumn{2}{c}{$\mathbf{N}$} & $\mathbf{\%}$ & $\mathbf{N}$ \\
\hline Before & 0 & 0 & 30 & 100 \\
After & 23 & 77 & 7 & 23.3 \\
\hline
\end{tabular}

The hormonal contraceptive acceptors who experienced complaints of leukorrhea before treatment were 30 subjects. After the treatment using a vaginal wash using a mixture of soursop and red betel leaves for 5 days with a frequency of washing twice a day, 23 subjects of hormonal contraceptive acceptors were recovered from leukorrhea complaints and 7 subjects were not fully recovered and still have leukorrhea complaints

Table 4. The Frequency Distribution of Research Variables Effectiveness of Soursop Leaf Decoction against Leukorrhea at Hormonal Contraceptive Acceptors in the Regional Public Service Agencies of Public Health Center in Tembelang, Jombang in the year of 2020

\begin{tabular}{lcccc}
\hline \multirow{2}{*}{ Soursop leaf Decoction } & \multicolumn{4}{c}{ Leukhorrhea } \\
\cline { 2 - 5 } & Recovered & \multicolumn{3}{c}{ Not Fully recovered } \\
\cline { 2 - 5 } & $\mathbf{N}$ & $\%$ & $\mathbf{N}$ & $\%$ \\
\hline Before & 0 & 0 & 30 & 100 \\
After & 21 & 70 & 9 & 30 \\
\hline
\end{tabular}

The hormonal contraceptive acceptors who experienced complaints of leukorrhea before treatment were 30 research subjects. After the treatment using vaginal washing of soursop leaf decoction for 5 days with a frequency of washing twice a day, It was obtained that 21 subject of hormonal contraceptive acceptors were recovered from complaints of leukorrhea and 9 subjects were not fully recovered and still have leukorrhea complaints

Table 5. the results of the T-test based on the pre and post-test of Soursop and Red Betel Leaf Decoction group and the Soursop Leaf Decoction group

\begin{tabular}{lcc}
\hline \multicolumn{1}{c}{ Group } & Mean & p-Value \\
\hline Pre and post test Soursop and Red Betel Leaf Decoction & 0.77 & 0.000 \\
Pre and post test Soursop Leaf Decoction & 0.70 & 0.000 \\
\hline
\end{tabular}


Table 5 shows that there is a difference in the effectiveness of soursop leaf decoction and a mixture of soursop and red betel leaf decoction against Leukorea on Hormonal contraceptive acceptors in the Regional Public Service Agencies of Public Health Center in Tembelang with significant statistical test results is $\mathrm{p}$ value $<0001$. The treatment of mixed soursop and Red betel leaves decoction can decrease leukorrhea complaints by $77 \%$ while soursop leaf decoction is also effective in decreasing leukorrhea complaints by $70 \%$ with significant statistical test results $\mathrm{p}$ value $<0.001$.

\subsection{Discussion}

\subsubsection{The effectiveness of soursop and red betel leaf decoction against leuchorea on hormonal contraceptive acceptors}

A mixture of soursop leaves (Annona muricata L) and red betel leaves (Pipercrocatum) based on the results of statistical tests significantly with a $\mathrm{P}$ value $<0.001$ and $77 \%$ effective can be used as an alternative to treat complaints of leucorrhea in women. Red betel decoction contains carvacrol which function is as disinfectant and anti-fungal so that it can be used as an antiseptic medicine to maintain oral health, cure vaginal discharge and odor. The substances in red betel have a major effect in reducing the symptoms of pathological vaginal discharge, such as carvacrol which can be used as an antiseptic drug. Flavonoids in red betel leaf has the function as antioxidant, antifungal, antiseptic, and anti-inflammatory. Alkaloids in red betel leaf also have antimicrobial properties and essential oils act as anti-bacterial and tannins which also have anti-bacterial power, the ethanol extract of red betel leaf shows antitrichomonas and the greater the concentration of the extract used, the more Trichomonas vaginalis cells die. The way to make decoction is by boiling 10 grams of red betel leaf in $500 \mathrm{ml}$.

Red betel soursop leaves (Pipercrocatum) is a plant that contains chemical compounds such as ßavonoids, alkaloids, saponins, tannins, and essential oils. The essential oil from red betel leaves contains flying oil (betlephenol), sesquiterpenes, starch, diatase, sugar and tanning substances and chavicol which have the power to kill germs, anti-oxidation and fungicides, antifungal which empirically reduces secretions in the vaginal opening and acute vaginal discharge13. Red betel leaf extract is able to kill the fungus Candida albicans which causes acute vaginal discharge and itching of the genitals. Soursop leaves (Annona muricata L) contain compounds of tannins, phytosterols, calcium oxalate and muricine alkaloids. Muricine alkaloids which are classified as phenolic compounds. Phenolic compounds can cause denaturation of membrane proteins, then these compounds can penetrate the nucleus and cause degradation of nuclear proteins resulting in cell death (in this case Candida albicans cells). Tannins in these leaves are thought to have effectiveness in inhibiting or killing the fungus Candida albicans. Tannins have the meaning of defense for the body, help repel plant predators, have antioxidant activity and are effective for antiseptics. Candida albicans is a fungus that is most often the cause of Leuchorea in women

Hormonal contraceptives contain the hormones of estrogen and progesterone which will inhibit the process of egg maturation, thicken cervical mucus, atrophy the endometrial walls so that fertilization and pregnancy do not occur. The side effect of excess progesterone and estrogen due to contraception is one of the complaints of leucorrhea. Leucorrhoea can occur in respondents who use hormonal contraceptives with high amounts of progesterone. Prolonged exposure to contraceptives will cause a decrease in the natural resistance of the uterine wall or cervix to trauma, leading to infection [9]. 
Abnormal vaginal discharge can occur in all genital infections (infection of the pubic lips, vaginal intercourse, cervix, supporting tissue, and in infections due to sexually transmitted diseases). The characteristics of pathological vaginal discharge are containing a lots of leukocytes, many of which occur continuously, change color (usually yellow, green, gray, and resemble milk), accompanied by complaints (itching, heat, and pain) and musty, fishy and foul $[1]$.

\subsubsection{The effectiveness of soursop leaf decoction against leuchorrhea on hormonal contraceptive acceptors}

Soursop leaf decoction (Annona muricata L) based on the results of statistical tests significantly with a $\mathrm{P}$ value $<0.001$ and $70 \%$ effective can be used as an alternative to treat complaints of leucorea in women. Soursop (Annona muricata L) can be an alternative medicine for fungal infections caused by candida albicans. Soursop leaves also have many uses, including as antibacterial, antifungal, anti-tumor, anti-convulsant, sedative, anti-parasitic, and cardiodepressant. Soursop leaves contain alkaloids, polyphenols, terpenes, acetogenins, flavonoids and lectins and terpenoids. The ethanol extract of soursop leaves shows antimycotic activity, especially against Candida albicans and can inhibit the growth of Candida albicans fungi with an average diameter of the inhibition zone of $12.5 \mathrm{~mm}$ which is categorized as strong. The damage to the cell membrane will disrupt the integrity of cellular components and cause the fungal respiration process to not occur. In the end, it results in insufficient energy for the active transport of nutrients so that fungal growth is disrupted [6].

Soursop leaves can be used to treat vaginal discharge in women because they contain antiseptic that can kill germs, namely phenol which has antiseptic properties 5 times more effective than ordinary phenols. To treat vaginal discharge, boil 10 soursop leaves in 2.5 liters of water, then the warm decoction can be used to wash the vagina [5]. 500 grams of $1000 \mathrm{ml}$ of soursop leaves contain terpenoids which can inhibit fungal growth. Soursop leaves contain acitrin oil, 50\% -65\% cineol, a-pinen, limonene and dipenten, contain acetogynous compounds, including asimycin, bulatasin and squamosin. At high concentrations, acetogenin compounds have the privilege of being as an antifeedent. Besides, they also contain annonaceous acetogenins which are able to kill cancer cells 10,000 times more powerful than adriamycin, which is commonly used in chemotherapy. Acetogenins can kill various types of cancer, such as colon, thyroid, phosphate, lung, breast, and pancreatic cancer and even ambient disease without damaging or disrupting healthy body cells [7].

\section{Conclusion}

Soursop and red betel leaf decoction is $77 \%$ effective and can be used as an alternative in healing complaints of leukorrhea in hormonal contraceptive acceptors who experience complaints of vaginal discharge/leukorrhea. Soursop leaf decoction is $70 \%$ effective and can be used as an alternative in healing complaints of leukorrhea in hormonal contraceptive acceptors who experience complaints of vaginal discharge / leucorrhea. Red betel leaf extract and soursop leaf can be used as a safe alternative medicine complementary against vaginal discharge in women of childbearing age. 


\section{References}

[1] G. Ayu Marhaeni, “Keputihan pada wanita”. Jurnal Skala Husada. no.13, vol.1, pp.30-38, 2016

[2] F. Firmanila, IY. Dewi, D. Kristiani ."Pengaruh Penggunaan Air rebusan daun sirih Merah terhadap Keputihan pada wanita usia subur (WUS) di wilayah Kerja Puskesmas Rawat Inap Tenayan Raya”. Jurnal Ners Indonesia.vol.6, no.1, pp.9-18, 2016.

[3] S. Khamees, "Characterization of vaginal discharge among women complaining of genital tract infection". International Journal Of Pharmacy \& Life Sciences.no.3, vol.10, 2012

[4] E. Rour., N. Travier., T. Waterboer, S. de Sanjosé., F. Xavier Bosch., I. chael Pawlita., "The Influence of Hormonal Factors on the Risk of Developing Cervical Cancer and Pre-Cancer": Results from the EPIC Cohor., 2016

[5] E. Rustanti, Z. Fatmawati, "Antimicosis activity of chloroform fraction of ethanol extract soursop leaves (Annona muricata, L.)". Medical laboratory analysis and sciences Journal, vol. 1, no. 2, pp,18, 2019.

[6] E. Rustanti, dan Z. Fatmawati, "The Active Compound of Soursop Leaf Extract (Annona muricata, L.) as Anti-vaginal discharge (Fluor albus)”. IOP conf. Series: Earth and Enviromental science 456, 2020

[7] Suwanti, Y.MR Koto, "Keputihan pada wanita usia subur menggunakan ekstrak daun sirsak". Jurnal Kebidanan dan Kesehatan Tradisional.vol 1, no.1, pp. 69-74, 2016

[8] Sulistyowati, A. Amalia. "Perbedaan Efektifitas Penggunaan daun sirih dan Bawang putih terhadap flour Albus". Surya. Vol 8, no 3, pp.38-44, 2016

[9] K. Kesehatan RI. 2011. "Formularium Obat Herbal Asli Indonesia", Jakarta

[10] B Murti. 2010. "Desain dan Ukuran Sampel Untuk Penelitian Kuantitatif dan Kualitatif di Bidang Kesehatan "edisi ke-2. Yogyakarta: Gajah Mada University Press.

[11] S. Priyanti., A. Dwi Syalfina. 2017. "Alat kontrasepsi dan Aktifitas Seksual yang berpengaruh terhadap Kejadian Keputihan”. Jurnal Berkala Epidemiologi. 5(3); 371-382

[12] W. Arniputri, B. Retna. 2015 Identifikasi Komponen Utama Minyak Atsiri Sirih Merah. Biodiversitas 8(2): 136-137

[13] R. Putriningrum, A. Khoiriyah. 2014. Analisis Tingkat Pengetahuan Pada Ibu Hamil Trimester III Menuju Proses Menyusui. Jurnal Kesehatan Kusuma

[14] Husada (Jurnal KesMaDaSka) STIKes Kusuma Husada Surakarta. 